\title{
ASPEK SOSIAL DAN NILAI PENDIDIKAN DALAM NOVEL BULAN \& BINTANG KARYA ITSMEINDRIYA
}

\author{
Nurul Fitriani*1, Sri Mulyati², Vita Ika Sari ${ }^{3}$ \\ ${ }^{*} 1,2,3$ Program Studi Pendidikan Bahasa dan Sastra Indonesia, Fakultas Keguruan dan Ilmu Pendidikan, \\ Universitas Pancasakti Tegal, Indonesia \\ e-mail: ${ }^{* 1}$ nurulfitriani519@gmail.com, ${ }^{2}$ srimulyati03@gmail.com, ${ }^{3}$ vitaidea859799@gmail.com
}

\begin{abstract}
ABSTRAK
Tujuan dari penelitian ini adalah mendeskripsikan aspek sosial dan nilai pendidikan yang terdapat pada novel Bulan \& Bintang Karya Itsmeindriya dan menjelaskan implikasi hasil pembelajaran di SMA. Penelitian ini menggunakan metode kualitatif. Sumber data penelitian ini adalah bentuk kalimatkalimat yang terdapat pada novel Bulan \& Bintang Karya Itsmeindriya. Wujud data penelitian ini berupa wacana yang menggambarkan aspek sosial dan nilai pendidikan. Teknik pengumpulan data dalam penelitian ini menggunakan teknik baca dan catat. Teknik analisis data menggunakan teknik deskriptif kualitatif. Teknik penyajian analisis data menggunakan teknik deskriptif.Teknik pengumpulan data dalam penelitian ini menggunakan teknik baca dan catat. Teknik analisis data menggunakan teknik deskriptif kualitatif. Teknik penyajian analisis data menggunakan teknik deskriptif.Hasil penelitian ini adalah mendeskripsikan aspek sosial dan nilai pendidikan terdapat jumlah data sebanyak 42 data dan itu terbagi menjadi 13 aspek sosial yang meliputi, 1) Aspek Budaya 5 data, Aspek Masyarakat 1 data, Aspek Politik 1 data, Aspek Adat Istidat 1 data, Aspek Norma 2 data, Aspek Idiologi 1 data, Aspek Agama 2 data, dan nilai pendidikan dalam novel Bulan \& Bintang Karya Itsmeindriya yang memiliki data sebanyak 29 data dan terbagi menjadi 8 nilai pendidikan karakter, yaitu: Nilai Religius 7 data, Nilai jujur 2 data, Nilai kerja keras 1 data, Nilai mandiri 1 data, Nilai rasa ingin tahu 8 data, Nilai bersahabat dan komunikatif 8 data, Nilai peduli sosial 3 data, Tanggung Jawab 1 data.
\end{abstract}

Kata Kunci : Aspek sosial, nilai pendidikan, novel Bulan Bintang.

\begin{abstract}
The purpose of this study is to describe the social aspects and educational values contained in the novel Bulan \& Bintang by Itsmeindriya and to explain the implications of learning outcomes in high school. This study uses a qualitative method. The data source of this research is the form of sentences contained in the novel Bulan \& Bintang by Itsmeindriya. The form of this research data is in the form of a discourse that describes social aspects and educational values. Data collection techniques in this study used reading and note-taking techniques. The data analysis technique used a qualitative descriptive technique. The technique of presenting data analysis using descriptive techniques.Data collection techniques in this study used reading and note-taking techniques. The data analysis technique used a qualitative descriptive technique. The technique of presenting data analysis using descriptive techniques. The results of this study are to describe social aspects and educational values, there are 42 data, where the data is divided into 13 social aspects which include, 1) Cultural Aspects 5 data, Community Aspects 1 data, Political Aspects 1 data, Aspects of Custom 1 data, Aspects of Norms 2 data, Aspects of Ideology 1 data, Aspects of Religion 2 data, and the value of education in the novel Bulan \& Bintang by Itsmeindriya which has 29 data and is divided into 8 values of character education, namely: Values Religious 7 data, Honest value 2 data, Hard work value 1 data, Independent value 1 data, Curiosity value 8 data, Friendly and communicative value 8 data, Social care value 3 data, Responsibility 1 data.
\end{abstract}

Keywords: Sosial aspects of education value. Novel Bulan Bintang.

\section{PENDAHULUAN}

Penelitian ini dilatar belakangi oleh adanya aspek sosial dan nilai pendidikan yang terkandung dalam sebuah karya sastra, khususnya novel. Sebagai sebuah karya sastra, novel banyak menyajikan aspek sosial dan nilai pendidikan melalui kemampuan pengarangnya dalam bercerita. Salah satunya adalah novel Bulan \& Bintang Karya Itsmeindriya. Oleh karena itu, masalah yang diangkat sebagai bahan penelitian adalah mendeskripsi aspek sosial dan nilai pendidikan yang terkandung dalam novel Bulan \& Bintang Karya Itsmeindriya. Karya sastra merupakaniihasil kreasi sastrawan melalui kontemplasi refleksi setelah menyaksikan berfungsi 
fenomena kehidupan dalam lingkungan sosialnya. Selain itu karya sastra merupakan sebuah karya yang mengidependen aspek keindahan di samping keefektifan penyampaian pesan (Setyorini 2015:289). Karya sastra merupakan cermin kehidupan manusia yang dibuat oleh sastrawan dengan tujuan menghibur, memberikan pelajaran, menyampaikan pesan, dan lain-lain untuk dipersembahkan kepada penikmat sastra. Oleh karena itu, karya sastra memiliki hubungan yang sangat erat dengan masyarakat. Ratna (2015:332) Karya sastra merupakan hasil ciptaan tulisan yang mengandung nilai-nilai kehidupan yang terdapat dalam masyarakat, sejatinya karya sastra tidak hanya mengandung nilai-nilai kehidupan saja, tapi karya sastra juga mengandung kehidupan. Kosasih (2014:2) Meurut Suwondo (2003: 5) Karya sastra adalah hasil kegiatan kreatif manusia yang berkaitan imajinatif, instuisi, dan abstraksi kehidupan. Berdasarkan uraian diatas dapat disimpulkan bahwa karya sastra memilliki hubungan yang sangat erat dengan masyarakat. Sastra adalah pengungkapan hidup dan kehidupan manusia yang tujuannya untuk menghibur kepada penikmat sastra.

Novel berasaliidari istilah novella dan novelle mengandung pengertian yang sama dengan istilah Indonesia novelet yang berarti sebuah karya prosa fiksi yang tidak terlalu panjang namun juga tidak terlalu pendek (Nurgiyantoro, 2009:9) Tarigan (2011:167) kata novel berasal dari kata laitin novellus yang diturunkan pula dari kata novies yang berarti "baru". Novel Menurut Boulton (dalam Atmazaki, 2005:39) termasuk jenis karya sastra termasuk prosa fiksi naratif, disamping roman dan cerita pendek. Novel adalah media hiburan. Bisa saja novel dijadikan sebagai informasi, edukasi, dakwah, dan sebagainya, namun semua itu harus disajikan dengan cara yang menghibur (Sambu,2013:44)

Apek sosial merupakan tingkah laku kehidupan sosial masyarakat yang mencakup semua permasalahan dalam lingkup yang kompleks seperti kebiasaan hidup, adat istiadat, tradisi, keyakinan, pandangan hidup, cara berfikir dan bersikap (Nurgiantoro dalam Nisak 2016:17) aspek sosial yang dibahas dalam novel Bulan \& Bintang Karya Itsmeindriya terdapat aspek yang ditonjolkan yaitu aspek sosial.

Nilai pendidikan merupakan topik yang menarik dan senantiasa aktual untuk dijadikan acuan agar nilai pendidikan dapat diterapkan. Menurut Diyarkarta adalah "Pemanusiaan" atau proses humanisasi, proses membentuk sosok profil manusia dengan mentalitas semangat human (manusiawi) yang memiliki penampilan fisik yang sehat, normal dan wajar kelakuanya. Nilai pendidikan yang dibahas dalam novel Bulan \& Bintang Karya Itsmeindriya yang akan ditonjolkan yaitu nilai pendidikan karakter.

Dalam materi pembelajaran bahasa dan sastra indonesia di SMA yang berkaitan dengan aspek sosial dan nilai pendidikan dalam novel terdapat kelas XII dengan kompetensi dasar 3.9 menganalisis isi dan kebahasaan novel. dan 4.9 meracang novel atau novelet dengan memperhatikan isi dan kebahasaan baik lisan maupun tulisa. Novel Bulan \& Bintang karya Itsmeindriya dapat digunakan sebagai bahan pembelajaran bahasa dan sastra indonesia di SMA. dalam novel tersebut mengandung banyak aspek sosial dan nilai pendidikan yang merupakan unsur instrinsik sebuah karya sastra novel yang dapat dikaji bersama guru dan peserta didik. Suatu bentuk novel yang dapat memberikan inspirasi kepada peserta didik di sekolah.

\section{METODOLOGI PENELITIAN}

Penelitian ini menggunakan pendekatan deskriptif yang bersifat kualitatif, karena data yang diperoleh dideskripsikan dengan kata-kata bukan dengan angka-angka. Penelitian memaparkan gambaran mengenai hasil penelitian dalam bentuk naratif. Peneliti mencari dan mencatat data secara cermat dan teliti dimana data tersebut beupa kalimat di dalam Novel Bulan \& Bintang Karya Itseindriya. Data tersebut dianalisis agar bisa ditarik simpulan kemudian dipaparkan secara apa adanya. Simpilan diatas sejalan dengan pendapat (Sudaryanto dalam Muhammad 2011:192) yang mengemukakan bahwa pendekatan deskriptif kualitatif yaitu penelitian yang dilakukan semata-mata hanya berdasarkan pada fakta-fakta yang ada atau fenomena yang secara empiris hidup pada penuturnya sehingga yang dihasilkan atau dicatat 
berupa perian bahasa yang biasa dikatakan sifatnya seperti potret atau paparan apa adanya.Sumber data pada penelitian ini yaitu berupa Novel Bulan \& Bintang sedangkan wujud data yaitu aspek sosial dan nilai pendidikan dalam Novel Bulan \& Bintang Karya Itsmeindriya.Teknik penyajian data dalam penelitian ini yaitu menggunakan teknik baca dan teknik catat. Peneliti membaca Novel Bulan \& Bintang Karya Itsmeindriya yang tujuannya untuk mengetahui apakah ada aspek sosial dan nilai pendidikan dalam Novel Bulan \& Bintang tersebut. sedangkan teknik catat yaitu, setelah membaca selanjutnya peneliti mencatat data pada Novel Bulan \& Bintang Karya Itsmeindriya yang mengandung aspek sosial dan nilai pendidikan. Hal ini bertujuan untuk mendapatkan data tertulis sebagai bahan analisis.

Proses analisis data yang dilakukan dalam penelitian ini yaitu: data yang telah digolongkan ke dalam aspek sosial dan nilai pendidikan kemudian di kelompokan ke dalam bentuk-bentuk aspek sosial dan nilai pendidikan.

\section{HASIL DAN PEMBAHASAN}

\section{Hasil Penelitian}

Berdasarkan analisis data tentang aspek sosial yang terdapat pada novel Bulan \& Bintang Karya Itsmeindriya adalah Aspek sosial tersebut berupa aspek budaya, masyarakat, politik, adat istiadat, norma, idiologi, dan agama. Berikut analisis aspek sosial yang terdapat pada novel Bulan \& Bintang Karya Itsmeindriya.

Tabel 1. Jenis Aspek Sosial

\begin{tabular}{|c|c|c|c|}
\hline No & Jenis Aspek Sosial & Faktor Penyebab Aspek Sosial & Frekuensi \\
\hline 1 & Aspek Budaya & $\begin{array}{l}\text { Bulan tak lupa membeli bunga } \\
\text { untuk diletakan di atas } \\
\text { pusara dua orang }\end{array}$ & 5 \\
\hline 2 & Aspek masyarakat & $\begin{array}{l}\quad \text { Bulan melakukan hal yang } \\
\text { tidak pernah dilakukan oleh } \\
1 \\
\text { gadis pada umumnya }\end{array}$ & \\
\hline 3 & Aspek Politik & $\begin{array}{l}\text { Ada sesuatu yang ingin Bulan } \\
\text { bicarakan dengan sahabat yang } \\
\text { am ini menusuknya dari belakang. }\end{array}$ & 1 \\
\hline 4 & $\begin{array}{r}\text { Aspek Adat Istiadat } \\
1\end{array}$ & $\begin{array}{l}\text { Kenapa dalam MOS harus ada } \\
\text { tradisi peserta nyari tanda tangan } \\
\text { para Pengurus OSIS, sih?! }\end{array}$ & \\
\hline 5 & Aspek Norma & $\begin{array}{l}\text { Neng, Bapak sudah capek dijahilin } \\
\text { mulu sama Neng Bulan }\end{array}$ & 2 \\
\hline 6. & Aspek Ideologi & $\begin{array}{l}\text { Bulan hanya tersenyum menanggapi } \\
\text { ucapan Bintang. Memang banyak } \\
1 \\
\text { orang yang meragukan cita-citanya }\end{array}$ & \\
\hline
\end{tabular}


7. Aspek Agama Dosa besar lo menzalimi anak yatim piatu 2

\section{Pembahasan}

Aspek sosial yang terdapat pada Novel Bulan \& Bintang Karya Itsmeindriya. Berikut pembahasan aspek sosial yang terdapat dalam Novel Bulan \& Bintang Karya Itsmeindriya. Aspek Sosial

Dalam penelitian ini penulis menemukan tujuh aspek sosial yang terdapat pada novel Bulan \& Bintang Karya Itsmeindriya. Aspek sosial tersebut berupa aspek budaya, masyarakat, politik, adat istiadat, norma, idiologi, dan agama.

a. Aspek Budaya

Dalam novel Bulan \& Bintang asek budaya dapat ditemukan data

Data (1)

"Bulan tak lupa membeli bunga untuk diletakan di atas pusara dua orang yang sangat disayangi Bulan, Nebula dan Orien. Umur Bulan dan Nebula masih begitu belia ketika mereka harus kehilangan sosok orang tua untuk selama-lamanya.." (Bulan \& Bintang: 188).

Data tersebut menggambarkan sifat Bulan dan kakak-kakak nya selalu melakukan budaya ziarah di makam kedua orang yang dicintai dan tidak lupa untuk membawa bunga untuk diletakan di pusara kedua orang tua nya. Hal tersebut menunjukkan bahwa Bulan dan kakak nya selau mengingat budaya untuk berziarah.

b. Aspek Masyarakat

Dalam novel Bulan \& Bintang aspek Masyarakat dapat ditemukan data.

Data (2)

“Bintang tidak pernah menyukai seseorang, tidak pernah memiliki kekasih, dan tidak pernah tertarik kepada siapa pun. Puluhan orang mencoba untuk mendekati dan menarik perhatian Bintang, tapi tidak ada yang berhasil. Namun Bulan berbeda. Bulan melakukan hal yang tidak pernah dilakukan oleh gadis pada umumnya.” (Bulan \& Bintang: 213)

Data tersebut menggambarkan sikap Bintang yang begitu cuek dengan orang sekitar, apalagi dengan lawan jenis nya. Bintang tidak pernah tertarik dengan siapapun. Tetapi setelah bertemunya gadis bernama Bulan, Bintang merasa tertarik dengan sikapnya yang begitu beda dengan gadis pada umunya. Dengan menimbulkan rasa suka dengan lawan jenis, Bintang saling berinteraksi dan tertarik dengan kecantikan Bulan. Hal demikian yang menunjukkan Bulan berkarakter masyarakat yang membuat Bintang bergaul dan berinteraksi.

c. Aspek Politik

Dalam novel Bulan \& Bintang aspek Politik dapat ditemukan data

Data (3)

"Bulan langsung mendekati Aster dan menariknya keluar ruangan. Ada sesuatu yang ingin Bulan bicarakan dengan sahabat yang malam ini menusuknya dari belakang. Aster langsung menepis genggaman tangan Bulan. Raut wajah Aster terlihat tidak merasa bersalah sama sekali”. (Bulan \& Bintang: 332)

Data tersebut menggambarkan Bulan begitu tidak percaya dengan kelakuan Aster, yang selama ini sudah Bulan anggap sebagai sahabat dekat. Kelakukan Aster tidak disangka melukai hati Bulan begitu hancur. Kejadian yang membuat tangan Bulan melayang untuk menampar Aster. Hal tersebut menunjukkan peristiwa aspek politik. 
d. Aspek Adat Istiadat

Dalam novel Bulan \& Bintang aspek Adat Istiadat dapat ditemukan data

Data (4)

"Kak Bulan!! Teriak segerombolan orang, Bulan menoleh dan mendapati adik-adik kelasnya mulai mendekat. Mampus!" umpat Bulan. Kenapa dalam MOS harus ada tradisi peserta nyari tanda tangan para Pengurus OSIS, sih?!". (Bulan \& Bintang: 21)

Data tersebut menggambarkan Bulan yang tanpa pikir panjang untuk mengambil ancangancang kabur dari segerombolan adik kelasnya, banyak berbagai macam pertanyaan membuat Bulan sesak napas. Bulan seperti maling yang tertangkap oleh warga membuat Bulan frustasi karena menjadi artis dadakan. Hal yang menunjukkan adat istiadat yang ada di sekolah, setiap tahun mengadakan kegiatan masa orientasi sekolah.

e. Aspek Norma

Dalam novel Bulan \& Bintang aspek norma dapat ditemukan data

Data (5)

" Telunjuk Pak Eman bergerak ke kanan dan kekiri di depan wajahnya. Bapak nggak bakal kasihan sama raut memelas, Neng, Bapak sudah capek dijahilin mulu sama Neng Bulan. Sekarang, Bapak enggak kasih toleransi lagi untuk Neng Bulan”.( Bulan \& Bintan: 10)

Data tersebut menggambarkan sikap Pak Eman bebar-benar sudah kelihatan kesal dengan Bulan, yang selalu datang ke sekolah terlambat membuat Pak Eman tidak memberikan toleransi lagi kepada Bulan yang hobi terambat masuk sekolah. Hal demikian menunjukkan aspek norma.

f. Aspek Ideologi

Dalam novel Bulan \& Bintang aspek ideologi dapat ditemukan data

Data (6)

"Bulan hanya tersenyum menanggapi ucapan Bintang. Memang banyak orang yang meragukan cita-citanya. Akan tetapi, itu membuat Bulan mengubur apa yang ia cita-citakan sejak kecil. Lagi pula, menjadi Dokter adalah permintaan terakhir Ayah dan Bundanya. Bulan berusaha mewujudkan permintaan tersebut, meski semua orang meremehkan kemampuan Bulan.” (Bulan \& Bintang: 193)

Data tersebut menggambarkan sikap Bulan yang begitu yakin ketika ditanya dengan citacitanya. Yang mungkin orang heran menjdi seorang Dokter itu tidak mudah tetapi keseriusan dan keinginan Bulan kuat untuk mewujudnya cita-citanya yang ingin menjadi seorang Dokter. Hal tersebut menunjukkan aspek ideologi.

g. Aspek Agama

Dalam novel Bulan \& Bintang aspek Agama dapat ditemukan data

Data (7)

"Nyesel karena sering jahatin dia, kan? Dosa besar lo menzalimi anak yatim piatu." (Bulan \& Bintang: 194)

Data tersebut menggambarkan sikap Libra yang menyindir Bintang, karena sudah menzolimi Bulan seorang anak yatim piatu. Bintang merasa bersalah kepada Bulan. Padahal niat Bintang tidak bermaksud untuk menzolimi gadis yang bernama Bulan itu. Bintang yang tidak ada belas kasihan dengan gadis bernama Bulan, gadis yang selalu di cap jelek oleh Bintang. Hal demikian yang menunjukkan sikap Libra berkarakter agama. 
Tabel 2. Jenis Nilai Pendidikan Karakter

\begin{tabular}{|c|c|c|}
\hline $\begin{array}{l}\text { No } \\
\text { Frek }\end{array}$ & $\begin{array}{l}\text { Jenis Nilai Pendidikan } \\
\text { ensi }\end{array}$ & Faktor Penyebab Aspek Sosial \\
\hline \multirow[t]{2}{*}{1} & Nilai Religius & $\begin{array}{l}\text { Nebula hanya mengirim doa } \\
\text { untuk orang tuanya di surga }\end{array}$ \\
\hline & 5 & \\
\hline 2 & Nilai Jujur & $\begin{array}{l}\text { Bulan yang menyatakan perasaan } \\
\text { dengan jujur dengan Bintang }\end{array}$ \\
\hline 3 & Nilai Kerja Keras & $\begin{array}{l}\text { bahwa Bulan menyukai Bintang. } \\
\text { Bulan tidak ingin tinggal setahun } \\
\text { lebih lama di sekolah hanya karena } \\
\text { sakit perut yang membuat dirinya } \\
\text { terpaksa membolos. }\end{array}$ \\
\hline \multirow[t]{2}{*}{4} & Nilai Mandiri & $\begin{array}{l}\text { mereka harus hidup mandiri tanpa } \\
\text { orangtua dan harus bekerja keras }\end{array}$ \\
\hline & 1 & demi membiayai kehidupannya. \\
\hline \multirow[t]{2}{*}{5} & $\begin{array}{l}\text { Nilai Rasa Ingin Tahu } \\
8\end{array}$ & Kenapa tiba-tiba lo ngajak \\
\hline & & gue ketemuan di sini? \\
\hline 6 & $\begin{array}{c}\text { Nilai Bersahabat } \\
8 \\
\text { dan Komunikatif }\end{array}$ & $\begin{array}{c}\text { Aster tetap mengakui Bulan Sebag. } \\
\text { sahabat }\end{array}$ \\
\hline 7 & Nilai Peduli Sosial & $\begin{array}{l}\text { Bulan membawa adik kelasnya yang } \\
\text { pucat menuju UKS untuk beristirahat }\end{array}$ \\
\hline \multirow[t]{2}{*}{8} & Nilai tanggung Jawab & $\begin{array}{l}\text { Orion harus kerja ekstra supaya } \\
\text { bisa nerusin bisnis Ayah gue, biar } \\
\text { gue dan Nebula bisa tetap hidup. }\end{array}$ \\
\hline & Jumlah & 29 \\
\hline
\end{tabular}

\section{Pembahasan}

Nilai pendidikan karakter yang terdapat pada novel Bulan \& Bintang Karya Itsmeindriya. Nilai pendidikan karakter tersebut berupa religius, jujur, kerja keras, mandiri, rasa ingin tau, bersahabat dan komunikatif, peduli sosial, dan tanggung jawab. Berikut pembahasan nilai pendidikan yang terdapat dalam novel Bulan \& Bintang Karya Itsmeindriya.

a. Religius

Dalam novel Bulan \& Bintang nilai relijius ditemukan data

Data (8) 
“ Bulan tak banyak bercerita. Ia dan Nebula hanya mengirim doa untuk orang tuanya di surga. Bagi Bulan, itu lebih penting daripada harus bercerita panjang lebar mengenai apa yang telah Bulan lalui.(Bulan \& Bintang: 188)

Data tersebut menggambarkan sikap Bulan dan Nebula yang begitu cinta kepada orang tuanya yang sudah meinggal, untuk mengirimkan doa. Bulan dan kakak nya Nebula, pergi berziarah untuk kemakamya. Hal tersebut menunjukkan Bulan dan Nebula berkarakter religius.

b. Jujur

Dalam novel Bulan \& Bintang nilai jujur ditemukan dalam data

Data (9)

“ Bintang hampir terdesak mendengar perkataan Bulan yang terlalu jujur. Akan tetapi, ia berusaha semaksimal mungkin untuk tidak terlihat salah tingkah. Ah benar, Bintang salah tingkah. Untuk pertama kalinya selama 18 tahun hidup, Bintang salah tingkah.” (Bulan \& Bintang: 181)

Data tersebut menggambarkan sikap Bulan yang menyatakan perasaan dengan jujur dengan Bintang bahwa Bulan menyukai Bintang. Ketertarikan Bulan dari Bintang, karena ketampanannya. Bulan berusaha memperlihatkan dirinya dipercaya oleh orang, terutama dengan Bintang orang yang Bulan suka. Hal demikian yang meyebutkan Bulan memiliki karakter jujur.

c. Kerja Keras

Dalam novel Bulan \& Bintang nilai kerja keras ditemukan dalam data

Data (10)

"Bulan tidak ingin tinggal setahun lebih lama di sekolah hanya karena sakit perut yang membuat dirinya terpaksa membolos. Lagi pula, Bulan telah bertekad, ia harus bisa mewujudkan kemauan orang tuanya yang ingin melihat Bulan sukses sebagai Dokter. Meski Bulan sendiri tidak tahu bisa melakukannya atau tidak.”(BB:243)

Data tersebut menggambarkan sikap Bulan ingin menujukkan Bahwa Bulan bisa melanjutkan ke Universitas Kedokteran yang di impikan. Bulan sangat bersungguh-sunguh untuk berusaha mewujudkan kemauan kedua orang tuanya yang ingin melihat Bulan sukses. Hal demikian menunjukkan Bulan berkarakter kerja keras.

d. Mandiri

Dalam novel Bulan \& Bintang nilai mandiri ditemukan dalam data

Data (11)

"Bulan menghela napas. Coba ayah sama bunda masih ada disini. Raut wajah nebula langsung berubah melihat bulan dengan wajah sendunya. Jujur, nebula juga merindukan kedua orangtua nya. Selama bertahun-tahun, mereka harus hidup mandiri tanpa orangtua dan harus bekerja keras demi membiayai kehidupannya. Nebula tidak kasiahan pada dirinya sama sekali, tapi ia kasihan pada Bulan. Mesti terlihat ceria, sebenarnya Bulan adalah sosok pendiam yang selalu merindukan orangtua dalam kehidupannya.”(Bulan \& Bintang: 67)

Data tersebut menggambarkan sikap Nebula menjadi mandiri ketika ditinggal kedua orangtua nya, dan harus bekerja keras untuk membiayai kehidupannya. Hal tersebut menunjukkan Nebula memiliki karakter mandiri.

e. Rasa Ingin Tahu

Dalam novel Bulan \& Bintang nilai rasa ingin tahu ditemukan dalam data 
Data (12)

"Kenapa tiba-tiba lo ngajak gue ketemuan di sini? Tanya Aster membuka percakapan, Bintang tipe orang yang sulit diajak bertemu apalagi sampai empat mata seperti ini. Karena itu, Aster yakin pasti ada hal penting yang ingin dibicarakan Bulan.”(Bulan \& Bintang: 219)

Data tersebut menggambarkan kecurigaan Aster kepada Bintang, yang tiba-tiba mengajak berbicara berdua tanpa orang lain mngetahuinya. Aster semakin penasaran dengan Bintang. Karena Aster mengetahui Bintang itu orang yang sulit diajak bertemu apalagi sampe berbicara empat mata seperti sekarang ini. Hal tersebut menunjukkan Aster mimiliki karakter rasa ingin tahu.

f. Bersahabat dan Komunikatif

Dalam novel Bulan \& Bintang nilai bersahabat dan komunikatif ditemukan dalam data.

Data (13)

"Aster benar-benar tidak habis pikir. Bagaimana bisa ia berteman dengan cewek seperti Bulan. Hobinya berhalusinasi dan memiliki tingkat kepercayaan diri yang sangat berlebihan. Aster sadar, seharusnya ia tidak berteman dengan Bulan. Namun, nasi telah menjadi bubur, Aster tidak mungkin meninggalkan Bulan. Terlalu kasihan, karena nantinya akan semakin menggila." (Bulan \& Bintang: 37)

Data tersebut menggambarkan sikap Aster tetap mengakui Bulan sebagai sahabat. Aster mengetahui sifat Bulan yang suka berhalusinasi tidak jelas. tetapi Aster selalu memperhatikan kesenangan Bulan dan selalu bekerja sama dengannya. berpikiran konyol tetapi Aster tetap mengakui sebagai sahabat walaupun sikap Bulan terkadang mendadak suka aneh. Hal tersebut meunjukkan bahwa Aster memiliki karakter bersahabat.

g. Peduli Sosial

Dalam novel Bulan \& Bintang nilai peduli sosial ditemukan dalam data

Data (14)

"Gue dan yang lain tahu, lo bakal semena-mena sama mereka. Bulan terus menyudutkan Pelangi. Kalau gue lihat lo kayak gini lagi, gue nggak bakal tinggal diam. Lo bakal dapat hukuman yang lebih parah dari pada hukuman gue. Jangan harap pacar lo bisa bantuin lo! Ancam Bulan sebelum pergi meninggalkan Pelangi. Ia membawa adik kelasnya yang pucat menuju UKS untuk beristirahat." (Bulan \& Bintang: 18)

Data tersebut menggambarkan kekesalan Bulan terhadap Pelangi yang sudah melakukan hukuman kepada adik kelasnya. Bulan tidak terima apa yang sudah dilakukan Pelangi. Bulan langsung memberi bantuan untuk adik kelasnya dan Bulan langsung membawanya ke UKS. Hal tersebut menunjukkan Bulan berkarakter peduli sosia

h. Tanggung Jawab

Dalam novel Bulan \& Bintang nilai tanggung jawab ditemukan dalam data Data (15)

"Sejak orang tua gue meninggal, Orion harus kerja ekstra supaya bisa nerusin bisnis Ayah gue, biar gue dan Nebula bisa tetap hidup. Setelah lulus, Orion langsung berangkat ke Singapura bersama sekretaris pribadi Ayah. Nebula ngelakuin hal yang sama, sekolah dan meneruskan bisnis keluarga gue yang ada di sini. Terkadang, gue kasian karena waktu Nebula kesita sama sekolah, orgaisasi, dan pekerjaannya. Bahkan gue harus buat kisah percintaan putih abu-abu Nebula hancur." (Bulan \& Bintang: 279) 
Data tersebut menggambarkan Orion yang harus bertanggung jawab untuk memenuhi kebutuhan adik-adiknya. Orion sebagai kakak tertua sudah kewajiban untuk melakukan tugas meneruskan bisnis ayahnya di Singapura, sedangkan Nebula dan Bulan tetap melanjutkan sekolahnya di rumah. Tetapi Nebula terkadang membantu kakak nya Orien bekerja di saat libur sekolahnya. Hal demikian Nebula memiliki karakter tanggung jawab

\section{SIMPULAN}

Dari kajian juga analisis ini tentang peralihan kode pada podcast "Deddy Corbuzier" adalah terdapat banyaknya variasi bahasa yang digunakan dalam video podcast dan terdapat banyak pula faktir penyebab terjadinya peralihan kode dalam pembicaraan podcast tersebut, selain itu juga terdapat informasi yang bermanfaat juga untuk dipelajari oleh siswa. Maka simpulan pada kajian ini diperoleh ialah sebagai berikut.

Jenis peralihan kode pada podcast "Deddy Corbuzier" terdapat dua jenis alih kode, meliputi alih kode intern, dan alih kode ekstern. a) alih kode intern meliputi: peralihan kode dari bahasa Indonesia ke bahasa bahasa Betawi dan peralihan kode dari bahasa Indonesia ke dalam bahasa Jawa. b) kemudian peralihan kode keluar atau ekstern ialah: peralihan kode bahasa Indonesia ke bahasa Rusia, peralihan kode bahasa Indonesia ke bahasa Rumania, dan peralihan kode bahasa Indonesia ke dalam bahasa Inggris.

Faktor-faktor penyebab terjadinya peralihan kode ke dalam atau intern meliputi: a) keinginan untuk membangkitkan rasa humor, b) Lawan tutur atau mitra tutur, c) Perubahan topik pembicaraan, d) penutur atau pembicara. Kemudian data yang diperoleh dalam percakapan video podcast tersebut terdapat alih kode ekstern meliputi: a) penutur atau pembicara, b) Perubahan topik pembicaraan, c) keinginan untuk membangkitkan rasa humor, d) mitra tutur atau lawan bicara

\section{REFERENCES}

[1] Amaliani,Shofi, Leli Triana, dan Agus Riyanto, "Alih Kode dan Campur Kode pada Proses Belajar Di TK Pertiwi Longkeyang dan Implikasinya", Jurnal Skripta., vol 6, no 2, 2020, [Online]. Available: https://journal.upy.ac.id/index.php/skripta/article/view/900

[2] Thesa, Khodiyo, "Penggunaan Alih Kode dalam percakapan pada jaringan whatsapp oleh mahasiswa knb yang berkuliah di Universitas Sebelas Maret", Journal of Linguistic, vol 2 , no 1, 2017, [Online]. Available: https://jurnal.uns.ac.id/pj1/article/download/1720/10076

[3] Munandar, Aris. "Alih Kode dan Campur Kode dalam Interaksi Masyarakat Terminal Mallengkeri Kota Makasar. Jurnal Eprint, 2018, [Online]. Available: https://jurnal.uns.ac.id/pjl/article/download/1720/10076

[4] Kholifah Umi dan Haryadi, "Wujud Pilihan Kode Tutur Mahasiswa Aceh pada Ranah Pergaulan di Semarang", Jurnal Seloka. vol 6, no 2, 2017, [Online]. Available: https://journal.unnes.ac.id

[5] Indriyani, Yekti, "Alih Kode dan Campur Kode Antara Penjual dan Pembeli Di Pasar Prembun Kabupaten Kebumen (Sebuah Kajian Sosiolinguistik)", Jurnal Bahtera, vol 6, no 12, 2019, [Online]. Available: http://ejournal.umpwr.ac.id/index.php/bahtera/article/view/6032

[6] Henaulu, Maryam dkk, "Alih Kode dan Campur Kode Penjual dan Pembeli Di Pasar Tradisional Namlea", Jurnal LOA: Jurnal Ketatabahasaan dan Kesusatraan, vol 15, no 1, 2020 , [Online]. Available: https://ojs.badanbahasa.kemdikbud.go.id/jurnal/index.php/loa/article/view/2170

[7] Fadilah, Efi, Pandan Yudhapramesti, Nindi Arist, "Podcast Sebagai Alternatif Distribusi Konten Audi”, Jurnal Kajian Jurnalisme, vol 1, no 1, 2017, [Online]. Available: https://jurnal.unpad.ac.id/kajian-jurnalisme/article/view/10562 
[8] Meleong, Lexy J., “Metodologi penelitian kualitatif”, 2017, PT Remaja Rosdakarya Offset, Bandung.

[9] Muhammad, "Metode Penelitian Bahasa”, 2011, Ar-Ruzz Media, Jogjakarta.

[10] Haryati, Alih Kode dan Campur Kode percakapan dalam film Ketika Cinta Bertasbih dan Implikasinya terhadap Pembelajaran Bahasa Indonesia di SMA, Universitas Pancasakti Tegal, 2018, Tegal. 